\title{
Estimation of Shadow Prices for Project Evaluation in Pakistan
}

\author{
MUHAMMAD ZUBAIR KHAN*
}

The purpose of this paper $^{1}$ is to estimate shadow prices of capital and labour for use in the social evaluation of projects. ${ }^{2}$ The Harberger approach [7] has been used here to estimate the shadow discount rate. Apart from being one of the few demonstrations of the empirical estimation by this approach in literature this is the correct method of estimating the shadow discount rate where the marginal social value is not equal to the marginal social cost of funds at market equilibrium due to the presence of various distortions.

The estimation, in this paper, of the shadow wage rate of unskilled labour of Pakistan improves upon other attempts by taking account of a number of factors not considered hitherto. Firstly, it takes account of the different flows of rural-urban migration to the various industrial cities to estimate more accurately the opportunity cost of employing labour in each city. Secondly, the estimate takes account of the changes in social cost brought about by changes in the consumption bundle of the immigrant labour and the physical relocation of labour. In addition the estimates have been derived under alternative assumptions regarding the marginal productivity of labour in the agriculture slack season.

The shadow prices estimated here are purely efficiency prices in contrast to social prices ${ }^{3}$ which take income distribution and growth consideration into account. The income distribution and growth considerations, while admittedly very important for policy making, have been left out of our analysis on the belief that policies other than the choice of particular projects can be used to attain objectives of growth and distribution. Moreover, the estimation of social prices involves translating of govern-

*The author is a Research Economist at the Pakistan Institute of Development Economics, Islamabad (Pakistan). He would like to thank Gary Pursell for providing the basic methodological guidelines used in this paper and Bela Balassa for the numerous comments on the earlier drafts of the paper. He also wishes to express his sincere appreciation of the editorial help rendered by S. H. H. Naqavi. Needless to say, the author retains the responsibility for the remaining errors.

${ }^{1}$ This article is based on the author's research completed in November, 1977 at the World Bank in the context of a Project entitled Export Incentives in Developing Countries.

${ }^{2}$ Although the shadow prices were estimated primarily for use in the estimation of Domestic Resource cost of the manufactured exports, they can be used in general for project evaluation because they are based on economy-wide data.

${ }^{3}$ The estimation of social prices is given in the article by Squire, Little and Durdag also appearing in this issue. 
ment policies into quantifiable elements using subjective judgments regarding the government's objectives, whereas the declared objectives of the government may not be clearly defined, or be subject to frequent changes if not contradicted sometimes by actual policy. Efficiency prices avoid such problems and are therefore a more reliable guide to policy making.

In the following pages, after first explaining the methodologies used here to estimate the shadow discount rate and the shadow wage rate, the paper presents the conclusions and policy implications of the analysis.

\section{THE SHADOW DISCOUNT RATE}

The shadow price of capital, or the shadow discount rate, represents the opportunity cost of capital to the national economy. Since the social marginal values and costs diverge at market equilibrium owing to discrepancies resulting from indirect taxes, tariffs or monopoly distortions, the shadow discount rate is defined here as a weighted average of the marginal social value and marginal social cost of investment resources, the weights being the proportions of investment funded by respective sources. The rationale behind using a weighted average is that an increase in demand for investment resources is likely to be met by both an increased supply of funds and a decrease in the use of funds in alternative uses. The opportunity cost of funds withdrawn from other uses is equal to the marginal product of capital in the entire economy.

This section first determines the sources of funds used for investment in Pakis$\tan$ and their share in the total investment undertaken during $1975-76$, the year for which the shadow discount rate is being estimated. Then the marginal cost to the national economy is determined for funds from each source before finally estimating the weighted average of the marginal costs to arrive at the shadow discount rate.

In the case of Pakistan, given the upward sloping supply curve of foreign capital, the demand for investment is met by foreign capital supplemented with capital from domestic sources, both private and public, in addition to the withdrawal of funds from projects with relatively low rates of return. Table 1 shows the contribution to total investment in 1975 - 76 by funds from all sources. The extent to which funds were diverted from alternative uses has been estimated indirectly for lack of better information. ${ }^{4}$

Furthermore, a distinction needs to be made between equity and debt capital to capture the different social values attached to each. The sources of finance listed

${ }^{4}$ Because private sector concentrates on consumer goods industries while public sector on the capital goods sector, the diversion of funds from the consumer to capital goods is indirectly estinated as the increase in the public in amounted to 30 percent of total investment over the period 1960 to 1975 . in Table 1 indicate that the debt/equity ratio for the public sector was $83: 17$ with equity defined as the sum of public savings and deficit finance. ${ }^{5}$ In view of the abnormally low government savings due to unforeseen expenditures during the year, the debt/equity ratio is estimated to range between $83: 17$ and $75: 25$ in the long run.

Table 1

Pakistan's Sources of Finance: 1975-1976

\begin{tabular}{lr}
\hline Public Sector & \\
Public savings & 76 \\
Current account surplus & 297 \\
Net capital receipts & 401 \\
Autonomous bodies savings & 183 \\
Provincial government's contribution & 1,512 \\
Inflationary finance &
\end{tabular}

Total: Public Saving

12,126

External Resources

14,595

Total: Public Sector

Semi-public Sector

Corporate Savings

Foreign Loans

Loans from Commercial Banks

200

946

1,484

2,630

Total: Semi-Public Sector

Private Sector

Foreign Resources

Equity

Loans through IDBP, ADBP, etc.

Total: Foreign Resources

Domestic Resources

Saving and capital market $\quad 2,994$

Loans from banks

Loans from ADBP, IDBP

Taccavi loans

Total: Domestic Resources

1,177

743

GRAND TOTAL

22,968

In the semi-public sector, corporate savings are low and the debt/ equity ratio is $92: 8$. The high proportion of foreign and debt finance during this year was mainly because the government used most of the corporate savings in the Annual

${ }^{5}$ Inflationary finance is considered a transfer of resources from the private to the public sector and is treated as an equivalent of taxation. 
Development Programme [14]. With the growth of the semi-public sector, their savings rate is likely to rise, suggesting a range of $90: 10$ to $80: 20$ for the debt/equity ratio in the long run.

In the private sector, the debt/equity ratio in $1975-76$ was $47: 53$. As the risk of nationalization subsides, equity investment is expected to increase substantially in the manufacturing sector with a long-run value in the range of 45:55 to 50:50.

\section{Marginal Cost of Funds}

Having identified the sources of funds, we shall now determine the marginal cost of funds from each source.

\section{i. Public Debt}

The cost of foreign borrowing is the marginal rate of interest paid on such loans adjusted for the effect of present borrowing on future interest rate and inflation.

In the pre-1975-76 period, almost all loans were from official sources which were available at concessional rates of interest. In fact, the average rate of interest on loans disbursed during the three years, 1973-74 to 1975-76, was 2.6 percent per annum. If all loan requirements of Pakistan could be met from these traditional sources, the average rate of interest on these loans, adjusted for a declining grant. element, would be the marginal cost of funds (i.e. 3\% p.a.). However, in veiw of the growing aid requirements of the country and the bleak near-term outlook for international assistance, Pakistan will have to borrow at the margin in the commercial markets as it had had to do in the recent past. In addition to being the marginal capital acquired by Pakistan, loans from commercial sources are on terms which reflect accurately the attitude of financial lender without any interest in supply contracts or in giving aid. The commercial interest rates, therefore, represent more correctly the marginal cost of foreign capital to the public sector. However, unlike official loans, terms on commercial loans change with variations in credit-worthiness of the country which is measured by its debt service ratio. Expecting the debt service ratio to rise over time on the basis of projections for the macro-economic parameters of Pakistan, the margin on commercial loans over the London Interbank Offer (LIBO) rate will rise correspondingly from $1 \frac{1}{2}$ percent at present to $2 \frac{1}{2}$ percent. ${ }^{6}$ Therefore, interest on commercial loans may be assumed to be in the range of 11 to 12 percent.

An adjustment for inflation needs to be made to help arrive at the real cost of borrowing to the domestic economy. The loan and its interest charges have to be repaid in foreign currency while the amount is fixed in nominal terms. If the price

${ }^{6}$ The average LIBO rate for the period 1973 to 1975 was 91/2 percent. of exports and imports has gone up by the time repayments are made, the borrower has to forego less in real terms to repay the same amount in foreign exchange. Because inflation rates for the future cannot be predicted accurately, we shall simply deflate the monetary interest rate by the rise in the price index of imports and exports for $1976-77$ to about 7 percent (adjusted downward by 1 percent for the downward trend in inflation).

The real marginal cost of borrowing from foreign sources would then range between 4 percent and 5 percent.

\section{ii. Public Savings}

Public savings, like private equity for a risk-averting government, bear an extra cost over and above the marginal cost of borrowing, equal to the risk premium. The premium implied in the private sector could be used as an upper limit for the risk premium in the public sector and we could adjust it down for differences in the risk involved in private and public investments. One may note, however, that the public investment is less risky simply because none of the political or nationalization risks which exist for the private sector are relevant to the public investments. The marginal return on loans in the private sector (supply price) or the consumption rate of interest is 4 percent [10]. The return on equity is estimated to be 8.2 percent, implying a risk premium in the private sector of 4.2 percent. Public investment risk may be half of this since it is concerned only with commercial risks rather than with political risks as well. Adjusting for the lower risk involved, the cost of public savings will be 2.1 percent higher than the cost of public debt. Hence the cost of public savings is 6.1 percent to 7.1 percent.

\section{iii. Capital in the Semi-Public Sector}

The marginal cost of funds used for investment in the semi-public sector will be the same as in the public sector since the division between the two is administrative only. However, a distinction is made in the paper to account for the different debt equity ratios in the two sectors.

\section{iv. Debt Capital in the Private Sector}

Capital in the private sector takes the form of equity which is directly invested by the saver, and debt capital which is loaned out by the private sector saver to the investor normally through a bank. The cost to the latter type of capital is the cost of foregone consumption reflected in the consumption rate of interest, plus the cost of mobilizing the savings and of investigating the project, i.e. the banking services.

The cost of foregone consumption, or the rate at which future consumption is discounted to equate with present consumption, is reflected by the real rate of interest paid on private saving. However, since there are different interest rates on 
bank deposits, varying with the period for which deposits are made, we shall use a weighted average of interest rates, the weights being the actual amounts deposited, particularly in the time deposit scheme. During 1975-76 the interest paid on savings deposits was 8 percent while on fixed deposits it ranged between 8 percent and $113 / 4$ percent. The average real interest rates paid on deposits over the past few years are shown in Table 2. The real return to savers is equal to the interest rate corrected for inflation in the consumer price index.

Table 2

Interest Rates and Inflation: $1972-73$ to $1975-76$

\begin{tabular}{lrrrc}
\hline & $1972-73$ & $1973-74$ & $1974-75$ & $1975-76$ \\
\hline $\begin{array}{l}\text { Weighted Interest Rate } \\
\text { (\%) on Time and Savings } \\
\quad \text { Deposits }\end{array}$ & 5.8 & 7.3 & 8.2 & 8.8 \\
$\begin{array}{l}\text { Inflation Rate (Consumer } \\
\text { Price Index) }\end{array}$ & 16.6 & 33.4 & 22.6 & 5.9 \\
$\begin{array}{l}\text { Real Interest Rate } \\
\text { Time Deposits (Rs. Million) } \\
\text { (Annual Average) }\end{array}$ & -10.8 & -26.1 & 2.9 & 2.9 \\
\hline
\end{tabular}

Source: [13],

The real interest rate on time deposits during 1975-76, when the inflation rate was at the "normal" level, indicates the society's discount rate more accurately. An altemative estimate is provided by Khan [10], who has estimated the consumption rate of interest based on a formula by Lal [11], to be 4 percent in real terms. Adding a 2.26 percent service charge, calculated as the difference between the average interest rates on deposits and on loans given out by the banking system, the real marginal cost of private debt capital is 6.3 percent if we use the consumption rate of interest and 5.2 percent if the real rate of interest on time deposits is used.

Another source of private sector debt capital is foreign loans. The marginal cost of total debt capital in the private sector is the weighted average of domestic and foreign debt capital. Foreign currency loans in 1975-76 were 27 percent of all debt capital in this sector, at the average cost of 4.5 percent. Therefore, the real cost of debt capital is 5.0 percent -5.8 percent in the private sector, with a mean value of 5.4 percent.

\section{Equity Capital in the Private Sector}

The marginal cost of private equity capital can be estimated from the average rate of return or profit rates on private investments adjusted for inflation and measurement errors. The profit rates reflect the sum of the cost of foregone consumption and the cost of undertaking the risk in investing equity capital in a project. Risk is a cost to the society because in the long run the risk premium will equal the average rate of loss on equity. The ratio of post-tax profits to total equity for the joint stock companies listed on the Karachi Stock Exchange during 1964-1974 is 12.25 percent [18]. To obtain the real profit rate, the ratio is adjusted for inflation, measured by the wholesale price index, which rose by 7.8 percent during $1975-76 .^{7}$

The opportunity cost of capital so estimated will understate the social cost because profits are understated. ${ }^{8}$ The estimates of understatement of profits are around 20 percent and, therefore, the adjusted profit rate is 8.2 percent with a range of 7.2 percent to 9.2 percent. Because investment trends in the past indicate that the non-industrial sector is unlikely to compete with manufacturing for resources in the long run we shall assume that the rates of return on equity in manufacturing are the highest or reflect the rates of return in the entire economy.

\section{Marginal Productivity of Capital}

The opportunity cost of capital must take into account the foregone marginal product of capital in alternative investments from which resources may have been withdrawn in order to finance a new project. Lyn Squire and van der Tak [19] define marginal product as the net economic return earned by a marginal unit of public investment at border prices. Of the two snethods suggested by them to estimate the parameter we shall use the method using micro data as the basis of our estimate because the macro data method, unless it estimates production functions, overestimates the parameter by using an average to estimate a marginal value and ignores the contribution of other factors. In addition, we shall adjust our results from the micro approach with the social rates of return on various projects undertaken recently in Pakistan.

The marginal product of capital is assumed to be the weighted average of return on equity and debt capital. The rates of interest on loans measure the rates of return on debt capital while profit rates reflect return on equity. Adjustments

${ }^{7} \mathrm{~A}$ further adjustment in the profit rates for the accelerated depreciation rates allowed by the taxation authorities has not been made for lack of data; however, it is unlikely to be large due to the appearance of the depreciation error in both the numerator and denominator of the profit rate. Furthermore, this bias is likely to be compensated by an error in the profit to the absence of revaluation of assets by firms causing profit rates to be overstated.

industrial industrial sector, profits were under-reported by 18 percent. Earlier in 1975-76, the Prime Minister's Inspection Team estimated that for the nationalization industries, profits were under-reported by 15 percent -25 percent in the pre-nationalization era. 
have been made for inflation, under-reporting of profits and border prices. The use of the average rate of return on capital when the deviations from the average reflect monopoly power, risk differentials and market fragmentation, implicitly assumes that capital is withdrawn from various alternative investments in equal proportions.

The rate of pre-tax profits (ratio of profits to paid-up capital and reserves) for large-scale manufacturing firms registered at the Karachi Stock Exchange ${ }^{9}$, was 18.63 in 1973, and we have taken it to be representative for 1975-76 since the former was a normal year.

The weighted average rate of interest on bank advances and loans for 1975-76 is 11.06 [20]. Adjusting for inflation at 7.8 percent and for under-reporting of profit by 20 percent (as already explained), we arrive at an adjusted pre-tax profit rate of 14.65 percent and an adjusted interest rate of 3.26 percent.

To adjust for the divergence between border prices and the prices used in private profitability, we shall multiply the marginal productivity of capital by the ratio of the official exchange rate (OER) to the shadow exchange rate (SER). From calculations of the shadow exchange rate made elsewhere by the author [9] the ratio is $0.96 .^{10}$

The debt equity ratio for total investment in the economy in 1975-76 was $75: 25$. Taking a range of $70: 30$ to $80: 20$ as the plausible debt equity ratio during normal periods, we have the following range for the value of marginal productivity of capital in the industrial sector of Pakistan (Table 3).

To compare our estimate of the marginal productivity of capital with the social rate of return of some recent projects in Pakistan, we shall first adjust our estimates for the differences between market wages and shadow price of labour. ${ }^{11}$

As will be shown in the later part of this paper, shadow wages of unskilled labour are about half of the market wages in the urban sector. Depending upon the market wage in the various industries and the labour-intensity of the industry, social costs of labour will be lower than the private costs and our estimates of social rates of return will be accordingly higher. Using the share of wages in total costs calculated by Guisinger and Irfan $[5 ; 6]$ for various industries, shadow wages will lower costs and raise profits by 6 percent. This implies an upward adjustment of 6 percent in the marginal productivity estimates to a range between 11.27 percent and 12.30 percent.

${ }^{9}$ The sales of these firms accounted for 70 percent of the total manufacturing sector sales

${ }^{10}$ No distinction has been made between public and private sector investment, although there is some evidence suggesting that private investment is in sectors with higher profit rates. there is some evidence suggesting that private investment is in sectors with higher profit rates. This is because public corporations are not pl
employment or production as the case may be.

${ }^{11}$ It is interesting to note that Squire, Little and Durdag estimated marginal productivity to be only one percent. This is because they have used on the marginal productivity rates of the public enterprises only.
Table 3

Marginal Productivity of Capital in Pakistan's Industrial Sector

Real Average Pre-Tax Rate of

Return on Equity

Real Return on Debt

Marginal Product of Capital (unadjusted)

(a) With Debt Equity Ratio $=70 / 30$

(b) With Debt Equity Ratio $=80 / 20$

Marginal Product of Capital (adjusted for Border Prices)*

(a) With Debt Equity Ratio $=70 / 30$

(b) With Debt Equity Ratio $=80 / 20$

*Adjustment based on $\frac{\mathrm{OER}}{\mathrm{SER}}=0.95$

Compared with the social rates of return on industrial projects, our estimates are conformable with figures in Table 4. However, to arrive at an estimate of the marginal productivity of capital in the entire economy, a weighted average of productivities in the industrial and agricultural sectors has been estimated. The average social rate of return on the three agricultural projects listed in the table, 18.6 percent, is used as the marginal product of capital in the agricultural sector. The estimate of the marginal product of total capital is, therefore, 14.0 percent - 14.5 percent with a mean value of 14.25 percent.

The disaggregated analysis of investment and the marginal cost of the various sources of funds to the different sectors provides us with different values for the marginal cost of capital for each sector. But since there is only one shadow price of capital for the whole economy we shall take the weighted average of the marginal cost of capital of each sector, the weights being the share of each sector in total investment in 1975-76.

Finally the estimate for the shadow discount rate for the economy has been arrived at by combining the range of values of the marginal cost of capital with the range of values for the marginal productivity of capital using appropriate weights as determined by the sources of funds. The range of values obtained for the shadow discount rate is $6.75-9.32$ with a mean value of 8.04 .

\section{THE SHADOW WAGE RATE (SWR) ESTIMATES FOR UNSKILLED LABOUR}

Consistent with the estimates of shadow price of capital, we shall be concerned with the efficiency shadow price of labour. The disutility of work is not con- 
Table 4

Social Rates of Return on New Projects

\begin{tabular}{lc}
\hline \multicolumn{1}{c}{ Projects } & $\begin{array}{c}\text { Social Rate of Return } \\
(\%)\end{array}$ \\
\hline Punjab Livestock Project & 20.00 \\
Railway Improvement Scheme & 6.25 \\
Fertilizer & \\
(i) Dawood Hercules & 28.40 \\
(ii) Fauji Agrico & 26.50 \\
Salinity Control SCARP VI & 19.00 \\
Till Drainage and Irrigation Project & 17.00 \\
5th Plan Project: Under 100\% capacity & \\
Steel & 1.00 \\
Fertilizer & 15.00 \\
Cement & 42.00 \\
\hline
\end{tabular}

sidered a social cost here because we shall define development narrowly as an increase in consumption and not necessarily leisure. The introduction of a reservation price of labour depending upon the disutility of work introduces a subjective element into the analysis, which is best ignored.

The shadow price of labour (or the shadow wage rate) is defined here as the opportunity cost of employing labour or the output foregone in its best alternative use. It will be different, therefore, for different levels of skills, and for labour from different sources of supply. The skill of the labour employed in a new project will be reflected in its productivity and hence will determine the output foregone in an alternative use. The source of labour supply is important because the additional labour employed may come from a pool of unemployed people, in which case employing of labour has no opportunity cost; or it may be withdrawn from one of a number of other sectors of the economy, causing a reduction in output which will differ for each sector.

In addition, the SWR will depend upon the relation between the marginal product of labour and foregone output, equating which may not be appropriate for the situation involved. For example, if the new project is located in the urban sector and for each labour employed in that sector, more than one labourer migrates from the rural to the urban sector, as in the Harris-Todaro type model, then output fore- gone is greater than the marginal product of labour in the rural sector. Similarly, under disguised unemployment, marginal product of labour may not be zero but output might not reduce when labour is withdrawn under certain assumptions - as explained later.

If the market for a particular type of labour is reasonably efficient, then the market wage is a good indicator of its marginal revenue product at market prices, as well as the foregone output. Skilled labour is quite scarce in Pakistan, especially now when a large number of them have left the country to work in the Middle East and elsewhere; so we shall assume its market wage to reflect its murginal revenue product in domestic market prices. The unskilled labour market in the urban sector is however distorted by both minimum wage legislation and union pressures, and wages do not equal their marginal product $[5 ; 6]$. This paper attempts to estimate the opportunity cost of employing unskilled labour in the urban sector.

In the case of labour requirement of a new rural project, unskilled labour will be withdrawn from the same sector. Since rural wages are lower than urban wages, there is no migration from the urban sector to fill in the vacancy of the withdrawn labour. For an urban project, workers will be drawn typically from the families or dependents of workers already living in the urban areas who would otherwise have been unemployed or in over-employed services, but the attraction of higher urban wages will induce further migration from the rural areas. Thus the final displacement is of labour in the rural areas even if it is indirect. In the absence of any empirically tested rural-urban migration pattern, we shall assume that only one labourer migrates for the creation of each new job in the urban sector. ${ }^{12}$

Agriculture sector's employment is characterized by a seasonality of demand for labour. During the peak demand season, labour is fully employed. Assuming that farmers maximize their profits, market wages can be regarded as equal to the marginal revenue product of labour. Since family farms (tenants) at the margin participate in the labour market, the wage reflects the marginal productivity of labour working on such farms as well. During the slack season, landless labour may be unemployed but usefully involved in productive activities like construction or maintenance of their homes or even employed at lower market wages on a farm helping in similar chores and reducing the farm families' working hours. Family farms may have excess labour supply even otherwise, with each number working fewer hours. When labour is withdrawn from the rural sector in Pakistan, the effect it has on total output during the slack season is open to debate unless empirically tested evidence can be presented. For lack of any such evidence, we shall use two different views on the opportunity cost of withdrawing labour during this season.

${ }^{12}$ Among the rural labour, following S. R. Khan [10], we assume that the sources of unskilled labour are the tenants and landless labour groups. 
Sen [17] argues that in general, for the family farm employment mode, a distinction should be made between labour time and the number of workers. When a worker is removed from the family unit during the slack season, the production does not fall because the other members increase the number of hours worked, keeping constant the total work time. The remaining members receive a higher share of total output as the number of recipients of total production has decreased, compensating them for the increased private disutility of work. This reasoning implicitly assumes that for any family member to be entitled to a share in output, he must work on the farm, and, secondly, that the supply price of labour effort is not an increasing function of work time in the relevant range. Hence the opportunity cost of family farm labour in the slack season, irrespective of its marginal productivity, may be zero.

On the other hand, another view is that the family farms output may easily decline when labour is withdrawn if we assume that the supply price of labour effort is an increasing function of work time so that the increased share in output, which the remaining family members receive, is not enough to induce an increase in labour time equal to the time the migrant worker previously worked. When total labour time is reduced, the output is also reduced. In the case of landless labour, although they are unemployed in the slack season, they are involved in productive activities like construction, maintenance of their homes, etc. Withdrawing of such labour, therefore, means a cost to the economy.

In our estimation of the SWR, we shall calculate separate values of SWR using both the variants of the slack season labour behaviour. When the opportunity cost is not zero, we shall assume that the slack season marginal product of labour is equal in value to half the peak season wages. This is rationalized in the following manner. Slack season wages are lower than peak season wages but the wage differential is not the same as the difference in marginal productivity of labour in the two seasons. The relationship between the slack season wages and marginal productivity is difficult to predict especially due to the lack of information regarding wages. But assuming that labour requirements during slack season are only half of those of the peak season, by sharing work, labour would work only half the time they worked in the peak season, reducing their marginal productivity to half of the peak season's, where the latter is indicated by peak season market wages.

The SWR of unskilled labour withdrawn from the rural sector is a weighted average of the output foregone in the two seasons, where the weights are the lengths of these two seasons. Output foregone calculated in market prices is adjusted to be expressed in border prices. If the total or some of the output foregone is a tradeable commodity, the value needs to be adjusted accordingly for the difference between the actual exchange rate and the shadow exchange rate.

In the case of Pakistan, the main exporting industries are located around Karachi, Lahore and Sialkot. We shall estimate the SWR for labour migrating to these areas. The SWR will differ for each city because the geographical areas from where the migrating labour originates are different for each city and, depending upon the local agricultural cropping patterns, the output foregone will vary accordingly.

Following Afzal [1], we shall divide Pakistan into three agricultural zones, the northern, central and southern zones, each relatively homogeneous with respect to soil, climate and other agronomic conditions. Then on the basis of the acreage data for four major crops - wheat, cotton, rice and sugarcane (covering 71 percent of all cultivable land) - we shall estimate the foregone output for each region when unit labour is withdrawn.

Finally, we calculate the SWR for labour in each city as the weighted average of the outputs foregone in each zone, where the weights are the proportion of immigrants in the total in-migrants to that city originating in the particular zone. ${ }^{13}$

Taking Peshawar Division as representative of the northem zone, Sargodha Division as that of the central zone, and Hyderabad Division as that of the southern zone, the average acreage under the four crops is derived from the Division level data. The wage, price and employment data are taken mainly from the survey by H. B. Eckert made for the Punjab Provincial Government in 1972 [3]. To convert the marginal product of labour into border prices, the market wage for each activity was multiplied by a ratio of the world price to domestic price of the respective commodity being produced. For the non-agricultural activity we have used a ratio of the official exchange rate to the shadow exchange rate as a conversion ratio. Since the proportions in which labour is 'withdrawn frow the rural tradeable goods production and non-tradeable goods production is undetermined, it has been assumed that labour is withdrawn from the various processes in proportion to the employment in the various production sectors. Agriculture, mining and manufacturing sectors are considered to produce only traded goods while construction, electricity, gas, water, commerce, transport and service sectors produce only non-traded goods.

The marginal product of labour originating in the tradeable goods sector ( 83 percent) needs to be adjusted further for the difference between the shadow exchange rate (SER) and the official exchange rate.

i. Estimates of SWR Under First Assumption of Slack Season Output Change

We shall first estimate the SWR assuming that the output foregone by withdrawing labour from the rural sector during the slack season is zero.

Data from the 1972 Population Census of Pakistan used by Helbock [8] show the originating area (districts) of migrant labour for the 12 largest cities.

The SWR estimate is Rs. 432 for Karachi and Rs. 434 for both Lahore and Sialkot. Overall SWR estimate is Rs. 433. These estimates of SWR need to be adjusted

${ }^{13}$ For distribution of such proportions in the urban centres of Pakistan, see [8]. 
for two additional costs which the economy has incurred to employ additional labour in the urban sector. The first is the physical cost of migrating from the rural to an urban sector. This transport cost will vary with the particular migration behaviour. For lack of information on migration behaviour and because the cost is spread over the lifetime earnings of the migrant, this adjustment has not been made.

A second adjustment suggested by Little and Mirrlees [12] is to allow for the higher prices in towns that reflect the cost of transportation of some of the consumer goods which are produced in the rural sector but now have to be transported to the urban sector to meet the requirements of the newly migrated labour. If prices in towns are higher for that reason, these transport costs should be added to the SWR.

In this paper the adjustment has been carried to its logical completion by adding a margin for the transport costs of rural supplied goods (food and fuel) and subtract a margin for the absence of transportation costs for urban-produced consumer goods which do not have to be transported now since the consumers have migrated to the same sector. In addition, we must add onto the estimates of SWR the difference in the housing rents between the two sectors.

Prices of all the consumption items are not available for the rural sector. We shall utilize data on wheat and paddy price differentials and assume, for lack of a better alternative, the same transport costs for the other goods.

On the basis of evidence given by Qureshi [16], marketing costs are taken to be 5 percent and transport margins to be 2 percent of the price for a transfer from the village to the mandi. Another 2 percent may be added for transportation costs to the urban centres. The latter figure is indicated by evidence from the author's firm level survey.

Supplemented by information on the consumption patterns of urban and rural workers $[2 ; 5]$ and the rent differentials, the adjusted shadow wage rates for the three cities are R.s. 621 for Karachi and Rs. 623 for both Lahore and Sialkot. Overall shadow wage rate amounts to Rs. 621 .

\section{ii. SWR Estimates Under Second Assumption}

Under the assumption that the value of output foregone or the marginal product of rural labour in the slack season is represented by half the market wage rate in the peak seasons, the SWR will be the weighted average of marginal product of labour in the two seasons, adjusted for border-market price differential, the shadow exchange rate, the transfer cost of consumer goods, and the rent differential in the rural-urban sectors.

The estimates of the SWR under the second set of assumptions are Rs. 932 for Karachi, and Rs. 935 for both Lahore and Sialkot. Overall SWR is estimated to be 933.
Differences in sources of labour supply do not make much of a difference to SWR estimates. The range for the first case varies between Rs. 621 for Karachi and 623 for Sialkot, a difference of less than 0.4 percent. Similarly, for the second case the variation is even less. Hence we are inclined to use the same value (an average of the city values) as an estimate of an overall SWR. The SWR estimate under the first set of assumptions is 30.6 percent of the urban market wage level (MWR) in 1971 while under the second it is 45.9 percent of the MWR.

As a safeguard against error in judgement regarding the output foregone in the slack season, we shall use the range of Rs. 621-933 (mean value Rs. 774.0) as the SWR of unskilled labour employed in the new urban projects. This estimate for 1970-71 may be relevant to $1975-76$ to the extent that increased mechanization and better seeds may have affected labour's productivity during this period or that money wages in the agriculture sector may have risen. Increased mechanization will increase labour's productivity but it will shorten the peak demand period as well. The SWR could have been affected in either direction. However, money wages have increased over the period 1960-73 at 2.2 percent per annum [4], implying that the SWR in 1975 under the various assumptions would be as follows:
Assumption
SWR Value
(i) Slack season marginal product $=0$
(ii) Six-day week slack season
= Rs. 690.00
$=$ Rs. 1036.00
(iii) Average range
$=$ Rs. 863.00

\section{CONCLUSIONS AND POLICY IMPLICATIONS}

The analysis concludes that in 1975-76 the shadow discount rate for Pakistan was in the $6.75-9.32$ range with a mean value of 8.04 . The estimates reflect a considerable insensitivity to the ranges of values used for some of the variables which determine the discount rate but whose accurate measurement has not been possible.

The empirical values obtained for the marginal social value and marginal social cost of investible funds, 14.5 percent and 5.5 percent respectively, confirm the $a$ priori expected divergence between the two variables, vindicating the appropriateness of the Harberger method of estimating the shadow discount rate for Pakistan. Moreover, by using economy-wide data to estimate the marginal social cost of funds, it is only logical to use data with a similar base to estimate the marginal social value (marginal productivity of capital). Furthermore, this allows the estimates to be used in the evaluation of project in every sector of the economy.

These estimates provide policy-makers with the cost of capital to the national economy adjusted for marginal changes expected in the near future, extending their usefulness for a period of time during which no major structural changes are 
brought about in the economy. The chief limitation of the estimates is the partia equilibrium framework within which they have been calculated with no adjustments made for distortions in all the other factor markets.

The estimates of the shadow discount rate provide a benchmark for the evaluation of projects by the internal rate of return method, suggesting the rejection of projects with rates of return lower than 8.04 percent and acceptance otherwise.

The estimates of the shadow wage rate vary greatly with the assumption made about the behaviour of labour supply during the agricultural slack season. From a low estimate of Rs. 690 per annum when we assume that the opportunity cost of labour during the slack season is zero, the SWR is estimated to be equal to Rs. 1036 when the slack season opportunity cost of labour is assurned half of that in the peak season. Both estimates of the SWR are in sharp contrast to the earlier notions of a zero shadow wage rate in a labour-surplus economy emanating from the Arthur Lewis type models. We have seen that the different results obtained here are due to the distinction made between the marginal productivity of labour and its opportunity cost in the presence of disguised unemployment.

The SWR estimates presented here relate to the unskilled labour class whose market wages do not reflect the opportunity cost of employing them due to the presence of distortions in the form of union pressures and minimum wage legislations. The analysis estimates that the shadow wage rate varies between 30.6 percent and 45.9 percent of the market wage rate, depending upon the estimate of the SWR.

In conclusion, the estimates of shadow prices caution against the use of market factor prices in the social evaluation of projects in Pakistan. The use of market wages in estimatirig the cost of labour and the interest rate on official foreign loans as the price of capital will both suggest the use of techniques of production which are more capital-intensive than those suggested by the comparative advantage of the country.

\section{REFERENCES}

1. Afzal, M. "Implications of the Green Revolution for Land Use Patterns and Relative Crop Profitability.” Pakistan Development Review. Vol. XII, No. 2. Summer 1973. pp. 135-147.

2. Chaudhry, M. Ghaffar and M. Anwar Chaudry. "Cost of Living Indexes for Rural Labourers in Pakistan.” Pakistan Development Review. Vol. XIII, No. 1. Spring 1974. pp. 26-39.

3. Eckert, J. B. Rural Labour in the Punjab : A Survey Report. Lahore: Planning and Development Department, Government of the Punjab. 1972.
4. Guisinger, S. E. "Wages and Relative Factor Prices in Pakistan." Washington, D. C. : World Bank. 1977. (Mimeographed draft)

5. Guisinger, Stephen and Mohammad Irfan. "Real Wages of Industrial Workers in Pakistan: 1954 to 1970.” Pakistan Development Review. Vol. XIII, No. 4. Winter 1974. pp. 363-388.

6. Guisinger, Stephen E. and Mohammad Irfan. "Inter-industry Differentials in Wages and Earnings in Pakistan's Manufacturing Sector." Pakistan Development Review. Vol. XIV, No. 3. Autumn 1975. pp. 274-295.

7. Harberger, A. C. "Survey of Literature on Cost-Benefit Analysis of Industrial Project Evaluation." In UNIDO, Evaluation of Industrial Projects. New York: United Nations. 1968.

8. Helbock, Richard W. "Differential Urban Growth and Distance Considerations in Domestic Migration Flows in Pakisian." Pakistan Development Review. Vol. XIV, No. 1. Spring 1975. pp. 53-84.

9. Khan, Mohammad Zubair. "The System of Export Incentives in the Manufacturing Sector of Pakistan." Unpublished Ph. D. dissertation, Department of Economics, The Johns Hopkins University, Baltimore (Md.), USA. 1978.

10. Khan, Shahrukh Rafi. "An Estimate of the Shadow Wage Rate in Pakistan." Pakistan Development Review. Vol. XIII, No. 4. Winter 1974. pp. 389-408.

11. Lal, D. Wells and Welfare. Paris: Development Centre for the OECD. 1972.

12. Little, I. M. D. and J. A. Mirrlees. Project Appraisal and Planning for Development. London: Heinemann Education Books Ltd. 1974.

13. Pakistan. Finance Division. Economic Adviser's Wing. Pakistan Economic Survey, 1976-77. Islamabad. 1977.

14. Pakistan. Planning Commission. Annual Plan, 1976-77. Islamabad. 1977.

15. Pursell, G. "Notes on a Shadow Discount Rate for the Ivory Coast." Washington, D. C. : World Bank. 1974. (Mimeographed)

16. Qureshi, Sarfraz Khan. "The performance of Village Markets for Agricultural Produce: A Case Study of Pakistan." Pakistan Development Review. Vol. XIII, No. 3. Autumn 1974. pp. 280-307.

17. Sen, A. K. Employment, Technology and Development. Oxford: Clarendon Press. 1975.

18. Sharwani, Khalid. "Some New Evidence on Concentration and Profitability in Pakistan's Large-Scale Manufacturing Industries." Pakistan Development Review. Vol. XV, No. 3. Autumn 1976. pp. 272-289.

19. Squire, Lyn and H. G. Van der Tak. Economic Analysis of Projects. Baltimore (Md.), USA: The Johns Hopkins University Press. 1975.

20. State Bank of Pakistan. Statistics Department. Banking Statistics of Pakistan, 1975-76. Karachi. 1978. 